\section{Trend in mortality due to \\ external causes in the State of \\ Espírito Santo, Brazil, from 1994 \\ to 2005}

\section{Evolução da mortalidade por causas externas no estado do Espírito Santo, Brasil, no período de 1994 a 2005}

\section{Ludmilla da Silva Viana Jacobson ${ }^{1}$}

Carla Lourenço Tavares de Andrade ${ }^{2}$

Cleber Nascimento do Carmo' ${ }^{1}$

Dennys de Souza Mourão'

Sandra de Souza Hacon'

${ }^{1}$ Oswaldo Cruz Foundation, Sergio Arouca National School of Public Health, Department of Endemic Diseases, Rio de Janeiro, Brazil.

${ }^{2}$ Oswaldo Cruz Foundation, Sergio Arouca National School of Public Health, Department of Health Administration and Planning, Rio de Janeiro, Brazil.

Corresponding author: Ludmilla da S. Viana Jacobson. Fundação Oswaldo Cruz. Sergio Arouca National School of Public Health. Department of Endemic Diseases, Rio de Janeiro, Brazil. Leopoldo Bulhões, 1480 - Manguinhos - 21041-210 - Rio de Janeiro, RJ, Brasil. E-mail: ludmillaviana@yahoo.com.br

\section{Abstract}

The aim of this study was to analyze the trend in mortality due to external causes in the State of Espírito Santo, Brazil, from 1994 to 2005, according to specific groups (traffic injuries, poisoning, intentional self-harm, assault), age group and gender. The trend analysis was performed with polynomial regression models, based on data from the Brazilian Ministry of Health's Mortality Information System. For all external causes, the trend was not statistically significant, but when it was stratified by gender and age group the results showed a downward trend in some strata. According to gender, the yearly increase in mortality rate was higher for men. In general, this increase was observed in all age groups. For traffic injuries, there was a decrease in the mortality rate, mainly for men. There was a decrease in deaths from poisoning for both men and women. Intentional self-harm showed an upward trend, especially for 50 and over age group. As a specific group, assault also showed a significant upward trend for under-34 age groups and for men.

Keywords: Trend in Mortality. External Causes. Espírito Santo. Brazil 


\section{Resumo}

O presente estudo tem como objetivo analisar a tendência da mortalidade por causas externas no estado do Espírito Santo, Brasil, durante o período de 1994 a 2005, por seus grupos específicos (acidentes de transporte, envenenamento e intoxicação, lesões autoprovocadas voluntariamente, agressões), faixa etária e sexo. A análise da tendência foi realizada através de modelos de regressão polinomial, com base no Sistema de Informação sobre Mortalidade (SIM) do Ministério da Saúde. As causas externas de mortalidade não apresentaram tendência significativa, porém quando estratificados por faixa etária e sexo os resultados mostraram tendência decrescente em alguns estratos. Em todas as faixas etárias, a taxa de mortalidade foi maior nos homens. Entre o grupo de acidentes de transporte houve um decréscimo na taxa de mortalidade, principalmente nos homens. Houve redução nos óbitos referentes a envenenamento e intoxicação, tanto para o sexo feminino quanto para o masculino. As lesões autoprovocadas voluntariamente apresentaram tendência crescente principalmente para a faixa etária de 50 anos e mais. O grupo específico das agressões apresentou tendência de crescimento significativa para a faixa etária até 34 anos e para os homens.

Palavras-chave: Tendência. Mortalidade. Causas Externas. Espírito Santo. Brasil.
Introduction

According to data from the World Health Organization, external causes of mortality are some of the leading causes of death in the world, mainly in the 15-44-year age group, and violence is now considered the world's main public health problem ${ }^{1,2}$.

In Brazil, since the 1980s, external causes account for the second cause of death in the country ${ }^{3,4}$. According to Souza \& Lima ${ }^{5}$, in 2003, external causes accounted for $12.5 \%$ of all deaths in Brazil, and their mortality rate reached approximately 72 per 100,000 inhabitants. The Brazilian States with the highest mortality rates due to external causes are Rio de Janeiro, Espírito Santo, Rondônia, and Pernambuco, all with more than 90 deaths per 100,000 inhabitants (www.datasus.gov.br, last accessed on May/02/ 07). In Espírito Santo, the mortality rate due to external causes increased from 94.5 per 100,000 inhabitants in 1994 to 97.5 per 100,000 inhabitants in 2005.

The State of Espírito Santo is located in the Southeast Region of Brazil, and its estimated population in the year 2005 was 3,408,365 (www.ibge.gov.br, last accessed May/02/ 07), with a population increase of approximately $2 \%$ per year and a population density of 67.21 inhabitants $/ \mathrm{km}^{2}$. The State's economy underwent an unprecedented transformation in the early 1970s. At that time it was still characterized by the predominance of the primary sector, mainly coffee monoculture. Economic transformation was based on industrialization backed by the installation of large industrial plants. After the first large industrial operations were set up, the State organized its industrialization strategy and now has an increasingly diversified its economy, in line with the globalization process. The State's economic standard became that of an export/import industrial complex. These changes redefined the State's morbidity and mortality profile.

As for the main causes of death in the State, external causes are currently the second cause of death, next only to cardio- 
vascular diseases. This is largely due to the increase in violence among younger age groups.

The current study aims to analyze the trend in mortality due to external causes in the State of Espírito Santo from 1994 to 2005 , according to specific groups, gender, and age groups.

\section{Methods}

An ecological time series study was performed, based on secondary data for deaths from external causes in the State of Espírito Santo, provided by the Ministry of Health through its Mortality Information System for the 1994 to 2005 period. For the years 1994 and 1995, the study used the $9^{\text {th }}$ Revision of the International Classification of Diseases (ICD), and for the years 1996 through 2005, the $10^{\text {th }}$ Revision was used, which required a code equivalence investigation.

Trend analysis used polynomial regression models. First-, second-, and third-order polynomial models were tested, using mortality rates due to external causes (number of deaths due to external causes per age group and gender, divided by the age group and gender population in the year) as the dependent variable $(\mathrm{Y})$ and the study year as the independent variable $(\mathrm{X})$. The independent variable was centralized by the mean point of the time series ${ }^{6}$ to avoid colinearity between regression equation terms.

The best model was chosen according to three criteria: (1) level of significance, i.e., the $\mathrm{p}$-value of variance analysis (ANOVA); (2) determination coefficient, i.e., the closer to 1 , the better the model's fit; and (3) residuals analysis. In addition, when the trend was not statistically significant, the regression model was chosen according to the determination coefficient.

Models were prepared for each specific group under study, according to age groups $(<15,15-34,35-49$, and $\geq 50$ years $)$ and gender variables. The specific groups were traffic injuries, poisoning, intentional selfharm, and assault.

Moreover, the study also presents morta- lity rates by triennia (1994-1996, 1997-1999, 2000-2002, 2003-2005) according to age group and gender. Rates were calculated using the following formula: (total number of deaths due to external causes per age group and gender in the triennium) / (age group and gender population in the middle of the triennium X 3 )

In order to compare mortality due to external causes among municipalities in Espírito Santo, mortality rates were calculated (number of deaths due to external causes in the triennium, divided by the specific population in the middle of the triennium X3) for each municipality by triennia (1994-1996, 1997-1999, 2000-2002, 2003-2005), after which we proceeded to standardization by age group through the direct method, using the State capital Vitória in the year 2000 as the standard population. Considering the economic and social changes in the State, we chose the last triennium for comparison. Thus, mortality rates were categorized by distribution quartiles for the 2003-2005 triennium. Mortality rates by municipality can be seen in thematic maps.

The R program and Excel were used to generate the results of this article.

\section{Results}

The number of deaths due to external causes from 1994 to 2005 in the State of Espírito Santo was lower for women than for men in every year in the time series. The results for age group vary according to specific causes of death and gender. Among the specific causes of death, assault was the chief cause for the entire period under analysis, mainly for the age group of 15 to 34 years (Table 1 ).

Table 2 shows the results of the trend analysis for mortality rates due to external causes according to specific groups, age groups and gender, for the State of Espírito Santo, from 1994 to 2005.

For all external causes, the trend was not statistically significant (level of significance $=5 \%$ ). However, for specific groups of death the trend was statistically significant, 
Table 1. Mortality rates (per 100,000 inhabitants) from external causes by triennium, age group, gender, and specific cause. State of Espírito Santo, Brazil, 1994-2005.

\begin{tabular}{|c|c|c|c|c|c|c|c|}
\hline \multirow[t]{2}{*}{ Triennium } & \multirow{2}{*}{\multicolumn{2}{|c|}{$\begin{array}{l}\text { Age groups } \\
\text { and Gender }\end{array}$}} & \multicolumn{5}{|c|}{ Causes of Death } \\
\hline & & & Traffic injuries & Poisoning & $\begin{array}{l}\text { Intentional self- } \\
\text { harm }\end{array}$ & Assault & $\begin{array}{c}\text { All External } \\
\text { causes }\end{array}$ \\
\hline \multirow[t]{8}{*}{ 1994-1996 } & $<15$ & M & 10.8 & 0.1 & 0.1 & 2.6 & 26.9 \\
\hline & & $F$ & 5.6 & 0.0 & 0.0 & 1.4 & 14.1 \\
\hline & $15-34$ & $M$ & 55.6 & 0.4 & 6.7 & 127.0 & 225.9 \\
\hline & & $\mathrm{F}$ & 11.4 & 0.3 & 2.5 & 12.6 & 32.1 \\
\hline & $35-49$ & M & 75.0 & 0.3 & 11.2 & 120.2 & 254.9 \\
\hline & & $\mathrm{F}$ & 15.7 & 0.5 & 3.3 & 13.2 & 38.2 \\
\hline & $\geq 50$ & M & 66.1 & 1.4 & 10.0 & 54.0 & 192.6 \\
\hline & & $\mathrm{F}$ & 22.0 & 0.7 & 2.2 & 7.6 & 56.2 \\
\hline \multirow[t]{8}{*}{ 1997-1999 } & $<15$ & $M$ & 9.9 & 0.0 & 0.1 & 3.7 & 26.6 \\
\hline & & $\mathrm{F}$ & 6.3 & 0.2 & 0.3 & 1.3 & 14.3 \\
\hline & $15-34$ & $M$ & 53.6 & 0.6 & 8.4 & 176.7 & 269.1 \\
\hline & & $\mathrm{F}$ & 10.9 & 0.0 & 1.7 & 15.3 & 31.8 \\
\hline & $35-49$ & $M$ & 63.1 & 0.4 & 9.2 & 127.2 & 237.7 \\
\hline & & $\mathrm{F}$ & 12.5 & 0.1 & 1.8 & 14.4 & 34.4 \\
\hline & $\geq 50$ & M & 67.9 & 0.4 & 10.2 & 53.9 & 181.5 \\
\hline & & $\mathrm{F}$ & 22.9 & 0.3 & 2.9 & 5.8 & 57.7 \\
\hline \multirow[t]{8}{*}{$2000-2002$} & $<15$ & M & 7.8 & 0.14 & 0.2 & 2.8 & 22.1 \\
\hline & & $\mathrm{F}$ & 4.3 & 0.0 & 0.4 & 1.6 & 13.3 \\
\hline & $15-34$ & M & 55.9 & 0.4 & 7.7 & 160.2 & 250.0 \\
\hline & & $\mathrm{F}$ & 9.3 & 0.1 & 1.3 & 13.4 & 26.8 \\
\hline & $35-49$ & $M$ & 64.8 & 0.2 & 9.5 & 108.6 & 219.6 \\
\hline & & $\mathrm{F}$ & 14.2 & 0.2 & 2.1 & 11.8 & 33.5 \\
\hline & $\geq 50$ & $M$ & 63.9 & 0.0 & 10.8 & 49.8 & 177.0 \\
\hline & & $\mathrm{F}$ & 16.5 & 0.3 & 0.9 & 3.5 & 47.0 \\
\hline \multirow[t]{8}{*}{ 2003-2005 } & $<15$ & $M$ & 5.8 & 0.1 & 0.2 & 4.2 & 20.8 \\
\hline & & $\mathrm{F}$ & 4.1 & 0.0 & 0.3 & 2.0 & 12.7 \\
\hline & $15-34$ & $M$ & 53.9 & 0.1 & 7.7 & 168.1 & 252.1 \\
\hline & & $\mathrm{F}$ & 9.3 & 0.05 & 1.8 & 13.2 & 26.9 \\
\hline & $35-49$ & $M$ & 61.6 & 0.2 & 11.2 & 100.2 & 208.1 \\
\hline & & $\mathrm{F}$ & 9.6 & 0.1 & 3.5 & 12.1 & 31.2 \\
\hline & $\geq 50$ & M & 67.0 & 0.3 & 15.9 & 50.6 & 202.5 \\
\hline & & $\mathrm{F}$ & 15.3 & 0.0 & 4.5 & 4.6 & 65.4 \\
\hline
\end{tabular}

except for traffic injury deaths, despite a low determination coefficient. For deaths from poisoning, the model showed a significant constant downward trend, which means that the mortality rate decreased each year. For intentional self-harm, the mortality rate showed a significant upward trend for the entire period. For assault, the model showed a statistically significant upward trend, but a non-constant increase per year.

Figures 1 and 2 illustrate the trend of the mortality rate by specific groups of death. 
Table 2. Results of polynomial regression models by specific causes of death, age group, and gender. State of Espírito Santo. Brazil. 1994-2005.

\begin{tabular}{|c|c|c|c|c|c|}
\hline & Age group / & nder & Model & $\mathrm{R}^{2}$ & $\mathrm{p}$ \\
\hline \multirow{9}{*}{ 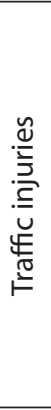 } & $<15$ years & M & $9.3-0.6 X-0.05 X^{2}$ & 0.87 & 0.000 \\
\hline & & $\mathrm{F}$ & $5.7-0.7 X-0.04 X^{2}+0.02 X^{3}$ & 0.58 & 0.064 \\
\hline & $15-34$ years & M & $54.7-0.13 X$ & 0.05 & 0.475 \\
\hline & & $\mathrm{F}$ & $10.1-0.8 X+0.01 X^{2}+0.03 X^{3}$ & 0.62 & 0.041 \\
\hline & $35-49$ years & M & $63.7+0.64 X+0.14 X^{2}-0.08 X^{3}$ & 0.70 & 0.017 \\
\hline & & $\mathrm{F}$ & $12.8-0.47 \mathrm{X}$ & 0.38 & 0.031 \\
\hline & $\geq 50$ years & M & $65.6-1.97 X+0.009 X^{2}+0.11 X^{3}$ & 0.50 & 0.112 \\
\hline & & $\mathrm{F}$ & $19.0-0.72 X$ & 0.35 & 0.041 \\
\hline & Total & & $26.99-0.17 X$ & 0.24 & 0.101 \\
\hline \multirow{9}{*}{ 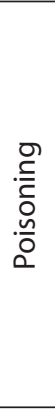 } & $<15$ years & M & $0.04+0.06 X+0.002 X^{2}-0.002 X^{3}$ & 0.36 & 0.282 \\
\hline & & $\mathrm{F}$ & $0.06-0.01 \mathrm{X}$ & 0.05 & 0.495 \\
\hline & $15-34$ years & M & $0.35-0.03 x$ & 0.09 & 0.334 \\
\hline & & $\mathrm{F}$ & $0.11-0.02 X$ & 0.17 & 0.186 \\
\hline & $35-49$ years & M & $0.28-0.02 X$ & 0.06 & 0.427 \\
\hline & & $\mathrm{F}$ & $0.09+0.03 X+0.01 X^{2}-0.003 X^{3}$ & 0.53 & 0.098 \\
\hline & $\geq 50$ years & M & $0.5-0.11 \mathrm{X}$ & 0.18 & 0.173 \\
\hline & & $\mathrm{F}$ & $0.15+0.06+0.01 X^{2}-0.006 X^{3}$ & 0.70 & 0.180 \\
\hline & Total & & $0.204-0.03 X$ & 0.36 & 0.002 \\
\hline \multirow{9}{*}{ 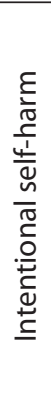 } & $<15$ years & M & $0.14+0.02 X$ & 0.28 & 0.077 \\
\hline & & $\mathrm{F}$ & $0.36+0.02 X-0.009 X^{2}$ & 0.20 & 0.369 \\
\hline & $15-34$ years & M & $7.6+0.07 X$ & 0.04 & 0.544 \\
\hline & & $\mathrm{F}$ & $1.8-0.09 \mathrm{X}$ & 0.24 & 0.109 \\
\hline & $35-49$ years & M & $10.1+0.05 X$ & 0.01 & 0.748 \\
\hline & & $\mathrm{F}$ & $1.8+0.03+0.07 X^{2}$ & 0.38 & 0.118 \\
\hline & $\geq 50$ years & M & $10.68+0.62 X+0.08 X^{2}$ & 0.70 & 0.005 \\
\hline & & $\mathrm{F}$ & $1.5+0.14 X+0.09 X^{2}$ & 0.43 & 0.079 \\
\hline & Total & & $3.76+0.10 X+0.015 X^{2}$ & 0.52 & 0.036 \\
\hline \multirow{9}{*}{$\begin{array}{l}\frac{n}{\vec{J}} \\
\text { 岕 } \\
\text { L }\end{array}$} & $<15$ years & $M$ & $3.4+0.13 \mathrm{X}$ & 0.35 & 0.043 \\
\hline & & $\mathrm{F}$ & $1.27+0.07 X+0.02 X^{2}$ & 0.44 & 0.072 \\
\hline & $15-34$ years & M & $168.47+3.46 X-0.9 X^{2}$ & 0.55 & 0.028 \\
\hline & & $\mathrm{F}$ & $14.44+0.03 X-0.07 X^{2}$ & 0.17 & 0.435 \\
\hline & $35-49$ years & M & $119.8-2.13 X-0.6 X^{2}$ & 0.74 & 0.002 \\
\hline & & $\mathrm{F}$ & 12.7-0.17X & 0.06 & 0.446 \\
\hline & $\geq 50$ years & M & $51.8-0.55 X$ & 0.20 & 0.142 \\
\hline & & $\mathrm{F}$ & $5.28-0.31 X$ & 0.30 & 0.066 \\
\hline & Total & & $50.5+0.65 X-0.26 X^{2}$ & 0.53 & 0.032 \\
\hline \multirow{9}{*}{ 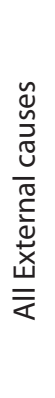 } & $<15$ years & M & $24.4-0.90 \mathrm{X}$ & 0.62 & 0.002 \\
\hline & & $\mathrm{F}$ & 13.7-0.23X & 0.26 & 0.087 \\
\hline & $15-34$ years & M & $259.8+1.9 X-0.90 X^{2}$ & 0.39 & 0.112 \\
\hline & & $\mathrm{F}$ & $29.6-1.9 X-0.02 X^{2}+0.06 X^{3}$ & 0.68 & 0.022 \\
\hline & $35-49$ years & M & $230.3-4.6 X-0.27 X^{2}$ & 0.87 & 0.000 \\
\hline & & $\mathrm{F}$ & $33.9-0.59 X$ & 0.35 & 0.044 \\
\hline & $\geq 50$ years & M & $1778.5-2.3 X+0.7 X^{2}+0.16 X^{3}$ & 0.72 & 0.012 \\
\hline & & $\mathrm{F}$ & $51.1-1.5 X+0.43 X^{2}+0.11 X^{3}$ & 0.55 & 0.078 \\
\hline & Total & & $99.7-1.0 X-02 X^{2}+0.06 X^{3}$ & 0.46 & 0.159 \\
\hline
\end{tabular}


$<15$

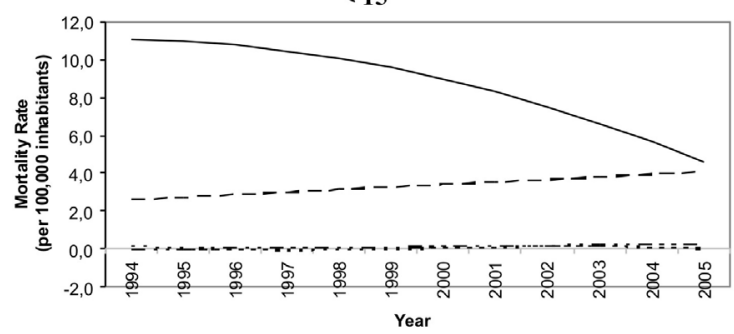

Traffic injuries $\cdots \cdot$ Poisoning $-\cdots-$ Intentional self-harm --- Assault

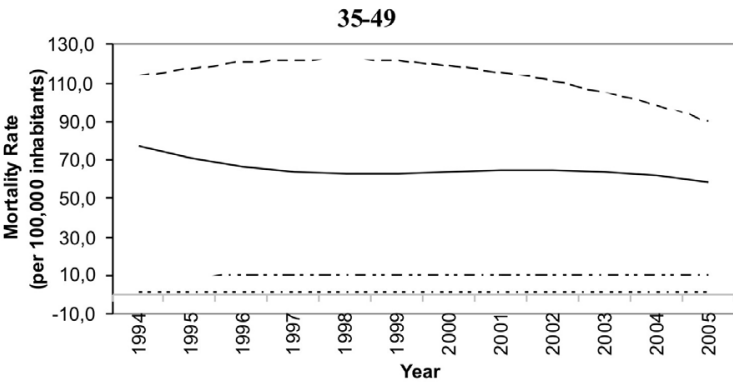

Traffic injuries $\cdots \cdots \cdot$ Poisoning $-\cdots-\cdot$ Intentional self-harm ---- Assault
15-34

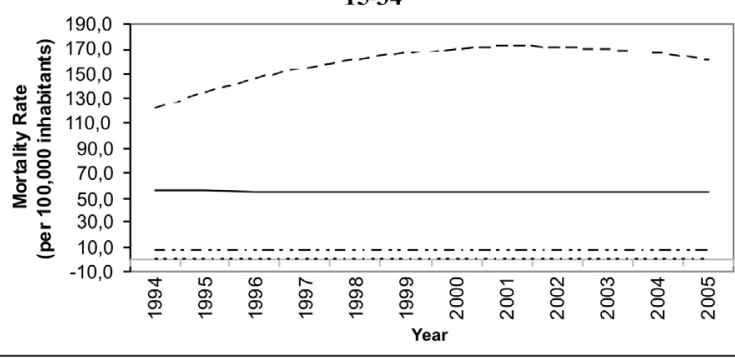

$\geq 50$

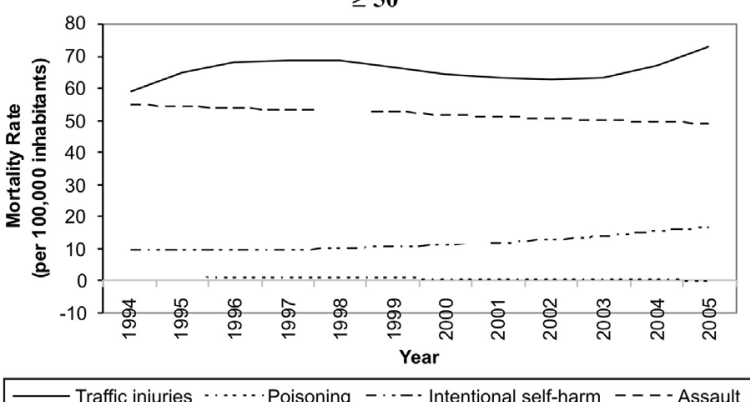

Figure 1. Trend in mortality rates due to external causes for men, by age group and cause of death. State of Espírito Santo, Brazil, 1994-2005.

Women

$<15$

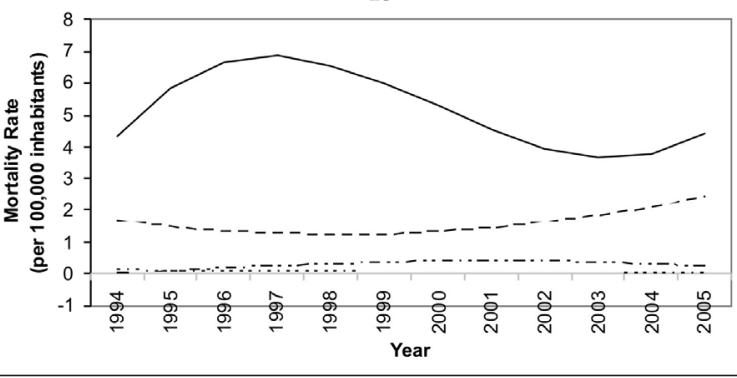

35-49

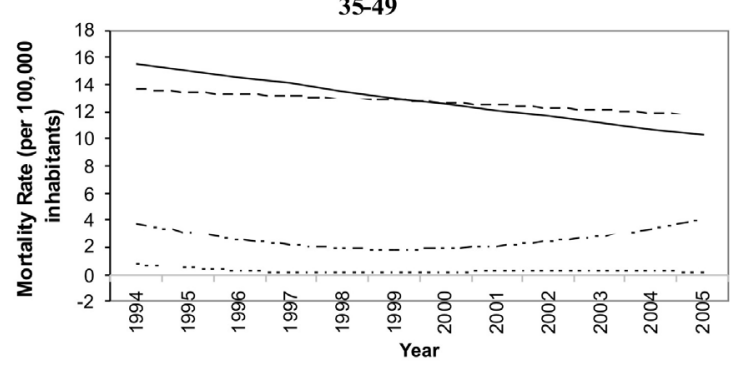

Traffic injuries $\cdots \cdots \cdot$ Poisoning $-\cdots-\cdot$ Intentional self-harm ---- Assault
15-34

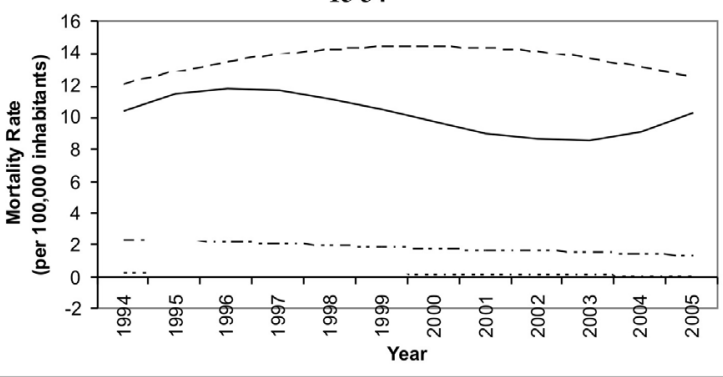

- Traffic injuries $\cdots \cdot \cdots$. Poisoning $-\cdots-\cdot$ Intentional self-harm ----Assault

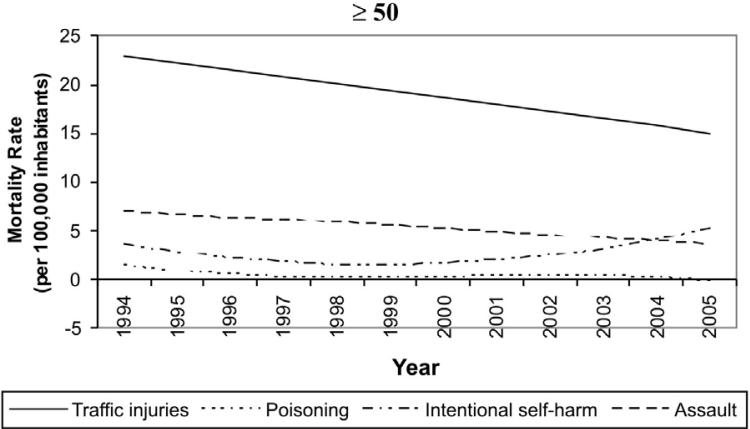

Figure 2. Trend in mortality rates due to external causes for women, by age group and cause of death. State of Espírito Santo, Brazil, 1994-2005. 
In the under-15-year age group, the mortality rate showed a significant trend (level of significance $=5 \%$ ) only among men . For all external causes, the model showed a significant downward trend in men. For specific groups of death due to external causes in this age group and men, traffic injuries showed a significant but non-constant downward trend, while assault showed a significant upward trend for the period. Among women, the series were stable. The other specific groups of death (poisoning and intentional self-harm) showed a stable time series.

As for the 15-34-year age group, in women, the model due to all external causes showed an increase in the mortality rate until 1996, but it started to decrease until 2003 when it started to increase again, while in men the mortality rate series was stable. The same was true for traffic injuries, but not for assault, whose model in men indicated an upward trend, and the model in women that indicated that the historical series was stable. Time series for deaths from poisoning and intentional self-harm were both stable.

As for the 35-49-year age group, the model for all external causes showed a significant downward trend for both men and women. The same was true for the specific group of assault, but only in men. The model for traffic injuries in men indicated a significant but non-constant downward trend, while the model in women showed a constant decrease. For poisoning and intentional self-harm, the series was stable throughout the period.

With regard to the 50 and over age group, among men, the model for all external causes showed a non-constant trend, while for women the series was stable. For both poisoning and assault, the series was stable throughout the period. Meanwhile, intentional self-harm showed a non-constant upward trend in men and traffic injuries showed a non-constant downward trend in women.

The results presented in Figure 3 show the trend in mortality due to external causes in the various municipalities of the State of Espírito Santo. Mortality rates in each study triennium showed an asymmetrical distribution, in which the mean rates (per 10,000 inhabitants) were 7.8 for 1994-1996, with a variation coefficient of $40.8 \%$; 7.4 for 1997-1999, with a variation coefficient of $42.2 \%$; 7.9 for $2000-2002$, with a variation coefficient of 34\%; and 8.4 for 2003-2005, with a variation coefficient of $32.8 \%$. These results showed an extremely wide variation among the municipalities of the State of Espírito Santo in relation to their mortality rates due to external causes. The municipalities located along the State's coastline, from Conceição da Barra to Guarapari, showed the highest mortality rates for every triennium, with the exception of 1997-1999. For 2003-2005, the lowest rates were found mainly in the south of the State and the mountain region (i.e., Santa Teresa), unlike the other triennia.

\section{Discussion}

External causes of mortality showed a stable series, but when they were stratified by gender and age group the results showed a downward trend in some strata. According to gender, the yearly increase in mortality rate was higher for men. In general, this increase was observed in all age groups. For traffic injuries, there was a decrease in the mortality rate, especially for men. There was a drop in the mortality rate from poisoning. Intentional self-harm (suicides) showed an upward trend, particularly in the 50 and over age group. Assault, which includes homicides, was another specific group with a significant upward trend, especially for under-34 age groups and for men.

Results by gender and age group corroborate those of other studies in Brazilian States. In São Paulo, a study by Kilsztajn et al. ${ }^{7}$ used statistical models to verify the relative risk of homicide by gender, age group, years of schooling, and race. The results pointed toward a greater risk among men, in the 15-34-year age group, in the black population, and in individuals with up to seven 

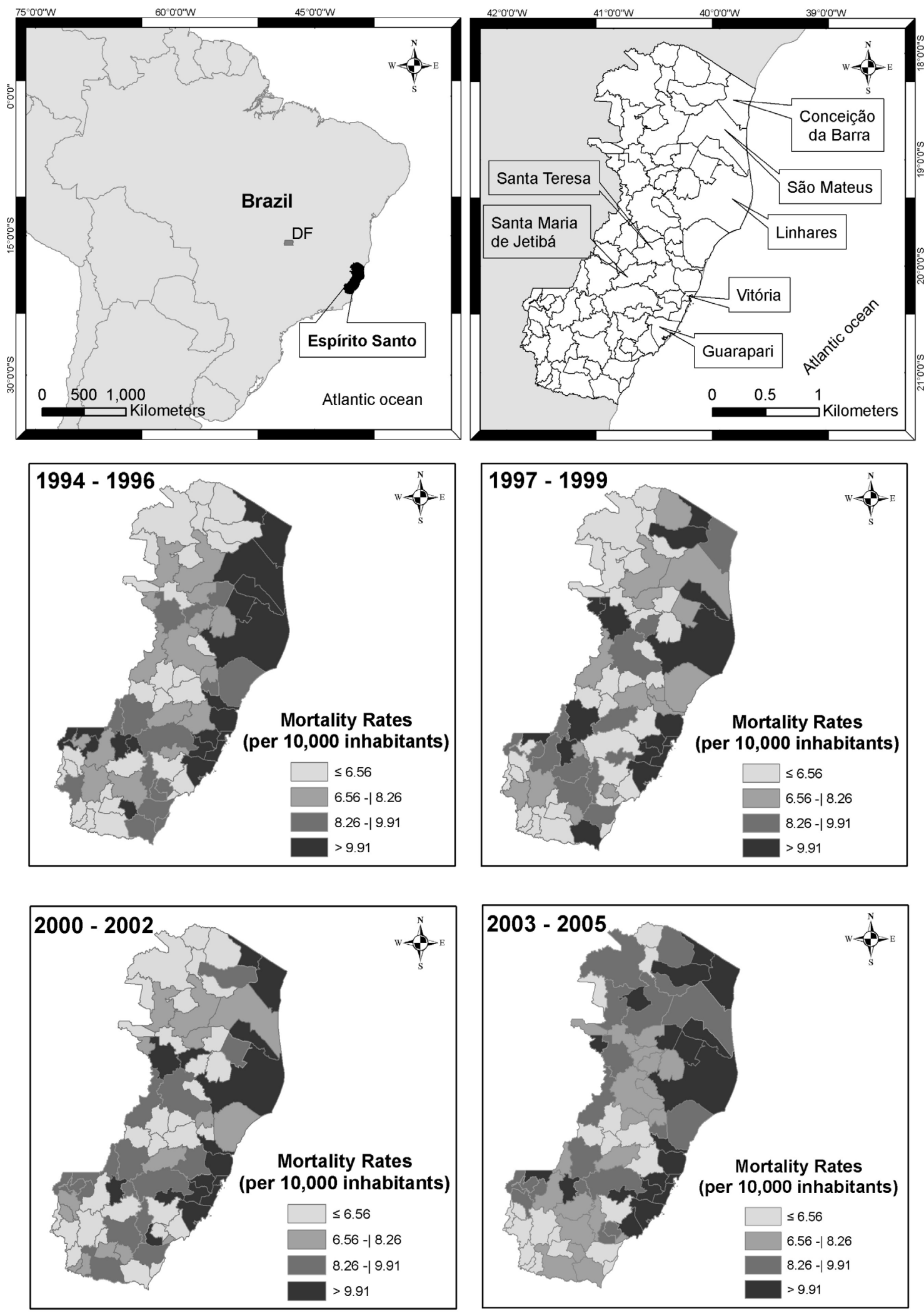

Figure 3. Trend in mortality rates due to standardized external causes, by triennium. State of Espírito Santo, Brazil, 19942005 
years of schooling. These results are similar to those for the State of Espírito Santo, given that the current study indicated a sharper increase in the mortality rate from assault among men and in this age group.

Meanwhile, the results were different from those in a study by Moraes et al. ${ }^{8}$ in São Luís, State of Maranhão, Brazil. Mortality from external causes showed a downward trend in the study period (1980 to 1999). However, the results for specific groups (traffic injuries and suicides) were similar to those in Espírito Santo.

Another study that deserves comparison was conducted in the State of Rio Grande do Sul, Brazil, by Faria et al. ${ }^{9}$, in which the focus was suicide. The authors confirmed high suicide mortality rates in the State and a gender difference, namely higher rates for men than for women. The same was observed in the data from Espírito Santo. A common characteristic in the two States is the intensive, extensive, and incorrect use of pesticides, especially in rural areas. The increase in suicide cases may be related in some way to increased use of certain pesticides (especially from the organophosphate group - www. anvisa.gov.br/toxicologia/index.htm, last accessed on Nov/06/ 08) that can cause neurological problems like depression, one of the main causes of suicide ${ }^{10}$.

An increase in mortality rates from external causes has been observed in Brazil ${ }^{5}$ and in other Latin American countries ${ }^{11}$ Dahlberg \& Krug emphasized that mortality rates from external causes vary according to the country's per capita GDP, meaning that poorer countries have higher rates than the wealthier ones, indicating a relationship between deaths from external causes and socioeconomic factors.

The trend in mortality rates due to external causes in the State of Espírito Santo, as indicated in the results above, principally for assault, may be explained by the social inequalities that are increasing, and which drive the younger and more financially underprivileged population to practice acts of violence. However, other social and economic indicators are also important for better assessing this trend. Some studies indicate the consumption of alcohol and other drugs and socioeconomic factors as the main determinants in external causes of mortality ${ }^{12-14}$.

Therefore, mortality rates from external causes may be indicators of a population's quality of life and important tools for public planning and administration.

The current study identified the trend in external causes of death in the State of Espírito Santo by specific groups, gender, and age group. The results are relevant as an initial investigation, but they are not sufficient to define the indicators leading to these trends, which require more in-depth research into the theme.

\section{References}

1. Krug EG, Dahlberg LL, Mercy JA, Zwi AB, Lozano R. World Report on Violence and Health. Geneva: World Health Organization; 2002.

2. Dahlberg LL, Krug EG. Violence a global public health problem. Ciênc Saúde Coletiva 2006; 11(2): 277-92.

3. Gawryszewski VP, Koizumi MS, Mello-Jorge MHP. As causas externas no Brasil no ano 2000: comparando a mortalidade e a morbidade. Cad Saúde Pública 2004; 20(4): 995-1003.

4. Minayo MCS. The inclusion of violence in the health agenda: historical trajectory. Ciênc Saúde Coletiva 2006; 11(2): 375-83.
5. Souza ER, Lima MLC. The panorama of urban violence in Brazil and its capitals. Ciênc Saúde Coletiva 2006; 11(2): 363-73.

6. Latorre MRDO. A mortalidade por câncer de estômago no Brasil: análise do período de 1977 a 1989. Cad Saúde Pública 1997; 13(Supl1): S67-S78.

7. Kilsztajn S, Carmo MSN, Sugahara GTL, Lopes ES. Vítimas da cor: homicídios na região metropolitana de São Paulo, Brasil, 2000. Cad Saúde Pública 2005; 21(5):1408-15.

8. Moraes JR, Silva AAM, Lamy-Filho F, Silva RA. Tendências da mortalidade por causas externas, em São Luís, MA, de 1980 a 1999. Rev. Bras. Epidemiol. 2003; 6(3): $245-54$ 
9. Faria NMX, Victora CG, Meneghel SN, Carvalho LA, Falk JW. Suicide rates in the State of Rio Grande do Sul, Brazil: association with socioeconomic, cultural, and agricultural factors. Cad Saúde Pública 2006; 22(12): 2611-21.

10. Mercante JPP, Peres MFP, Guendler V, Zukerman E, Bernik MA. Depression in chronic migraine: severity and clinical features. Arq Neuro-Psiquiatr 2005; 63(2-A): 217 20.

11. Yunes J, Zubarew T. Mortalidad por Causas Violentas en Adolescentes y Jóvenes: Un Desafío para la Región de las Américas. Rev Bras Epidemiol 1999; 2(3): 102-71.
12. Rutherford A, Zwi AB, Grove NJ, Butchart A. Violence: a priority for public health? (part 2). J Epidemiol Community Health 2007; 61: 764-70.

13. Väli M, Lang K, Soonets R, Talumäe M, Grjibovski AM. Childhood deaths from external causes in Estonia, 20012005. BMC Public Health 2007; 7: 158.

14. Kalediene R, Starkuviene S, Petrauskiene J. Social dimensions of mortality from external causes in Lithuania: do education and place of residence matter? Soz_Praventivmed 2006; 51(4): 232-9.

Recebido em: 11/04/08

Versão final reapresentada em: 19/11/08 Aprovado em: 11/12/08 